\title{
Altitudinally coordinated pattern of plant community structure in the Shivapuri National Park, Nepal
}

\begin{abstract}
Shalik Ram Sigdel ${ }^{1}$
Study on plant community structure was undertaken in different altitudinal ranges of Shivapuri National Park. The general objective of this study is to analyse different plant community structure in Shivapuri National Park with regards to altitudinal variation. The forest was divided into three distinct altitudinal ranges on the basis of dominancy. In each altitudinal range standard quadrats method was applied for vegetation analysis. The highest number of species was found in site II. All the ecological parameters of the plant species were higher in site II except Basal Area of tree that was highest in site III. The pattern of distribution of plant species was not uniform according to altitude. At higher elevation, the forest was mature with almost closed canopy and trees were large; so the tree density was low. Species richness was highest in site II. Species diversity among tree and shrub species was higher in site I. But for herb species diversity was higher in site II for both seasons. Such type of variations may be due to nature of soil i.e. acidity, nutrient availability and other micro-climatic factors. The most noteworthy thing was that variation in flower colour of $R$ hododendron arboreum i.e. deep scarlet at low altitude, but it gradually changed into pinkish white as altitude increased.
\end{abstract}

Key words: Altitude, Density, Plant community, Species diversity

$\mathbf{N}$ epal, a Himalayan Country, rises from the Indo-Gangatic plain, about $60 \mathrm{~m}$ asl in the south to world's highest peak, the Mount Everest $(8,848 \mathrm{~m}$ asl $)$ in the north. With increasing altitude, vegetation changes from tropical, through subtropical and temperate, to alpine (Stainton, 1972; Numata, 1983; Jackson, 1994). The boundaries of these vegetation zones are subject to much variation, being sometimes abrupt and sometimes gradual, in relation to various local factors such as topography, climate and aspect. There is a great variation in the vegetation along the rainfall gradient across the country - from the high rainfall area in the east to the low rainfall in the west. Thus, Nepal's geographical, altitudinal and climatological conditions taken together with various local factors account for the high species richness within the country's geographical area of $147,181 \mathrm{~km}^{2}$, extending along the Himalayan range.

Nepal covers only $0.1 \%$ of the world's total land area, which is well known for different types of flora within a short distance. The angiospermic flora of Nepal is unique. It has one of the richest floras in the world as far as the diversity of angiospermic taxa is concerned. Nepal has a share of $2.6 \%$ of the world's flowering plants (Chaudhary, 1998). It has been believed that around 7,000 species of flowering plants are present in Nepal, however only 5,636 species has been reported in the publication of DPR, 2001. But 6666 species of flowering plants has been reported in the recent publication (Bhuju et al, 2007).

Vegetation of Nepal has been divided into following six bio-climatic zones (Dobremez, 1980): Topical (< $1000 \mathrm{~m})$, sub-tropical $(1000-2000 \mathrm{~m})$, temperate $(2000 \mathrm{~m}-3000 \mathrm{~m})$, sub-alpine $(3000-4000 \mathrm{~m})$, alpine $(4000-5000 \mathrm{~m})$ and nival $(>5000 \mathrm{~m})$. Forest is mainly found from tropical to temperate region. TISC (2002) revised the forest classification and mentioned 33 types.

Sub-tropical to temperate region has $41.14 \%$ of total forest in Nepal (DFRS, 1999). The subtropical region has Schima-Castanopsis forest with other deciduous species in the east and central Nepal and Pinus roburghii forest in the west. The major associates in the former are Engelhardia spicata, Acer oblongum, Pyrus pashia, Eurya acuminata, Myrica esculenta etc. but in the later the associates are Myrica esculenta, Lyonia ovalifolia, Quercus lanata, Q. incana, Rhododendron arboreum etc.

It is essential to understand the local and regional pattern of vegetation distribution, stratification in resource availability and for the management of forest. In addition to climate, other factors such as 
biotic interactions also determine the vegetation type and their vigour. Since Shivapuri National Park is watershed of Bagmati River and one of the main sources of drinking water for Kathmandu valley, forest type and ecological balance of the region directly determine the quantity, quality and sustainability of water supply to this capital city. It is anticipated that the present study provides baseline information for developing sustainable management strategy, which is of utmost importance for uplifting the conservation of natural resources.

\section{Materials and methods}

\section{Study area}

Shivapuri National Park $\left(27^{\circ} 45^{\prime}\right.$ to $27^{\circ} 52^{\prime} \mathrm{N}$ and $85^{\circ} 15^{\prime}$ to $85^{\circ} 30^{\prime} \mathrm{E}$; altitude range from $1366 \mathrm{~m}$ to $2732 \mathrm{~m}$ asl and area $144 \mathrm{sq} \mathrm{m}$ ) lies at about $12 \mathrm{~km}$ north of Kathmandu valley. The Park is the source of high quality drinking water. The Shivapuri area provides about 1 million cubic litre of water per day (DNPWC, 2003). It is the watershed of Bagmati, Bishnumati, Nagmati, Syalmati, Sani Khola, Thuli Khola and Alle Khola. The most important objective of establishing the Shivapuri National Park is to increase the supply of high quality drinking water through the conservation and rehabilitation of the watershed. The park covers 23 village development committees of Kathmandu, Nuwakot and Sindhupalchowk districts.

The Land Resource Mapping Project (1984) classified forest of this Park into two types: deciduous mixed broad-leaved forest and coniferous chir-pine forest. Here subtropical and temperate type of vegetation is prominent. The subtropical zone is dominated by Scbima wallichii, Castanopsis indica, C. tribuloides and Pinus roxburgbii. The common associates are Almus nepalensis, Prunus cerasoides, Engelhardia spicata and Quercus glauca. The shrubs include Mussaenda frondosa, Osbekia stellata, Hypericum cordifolium andPhyllanthus parvifolius. At higher elevations, mixed temperate forest of oak (Quercus lanata, Q. semecarpifolia) and Rhododendron (Rhododendron arboreum) are predominant. The common associates are Lyonia ovalifolia, Myrica esculenta, Q.lamellosa, Symplocus sp., Rbus sp, Gaultheria fragrantissima, Potentilla fulgens, Hedyotis scandens, Rubia manjith (Chaudhary, 1998).

\section{Data collection and analysis}

A field reconnaissance survey was executed in the Shivapuri National Park area from last week of July to first week of August 2003. The purpose of the initial exploration was to assess the feasibility of this work. From this exploration, southern part of the park was selected for this study.

The study area $(1600 \mathrm{~m}$ to $2732 \mathrm{~m})$ has three distinct types of forests along the altitudinal gradients; Pinus roxburgbii forest (1600m -1800m), Quercus - CastanopsisRhododendron forest $(1900 \mathrm{~m}-2300 \mathrm{~m})$ and Q. semecarpifolia - Rhododendron arboreum forest (2400m-2732m) (Dahlen,1993). They are designated as site I, II and III respectively. The vegetation sampling was done by quadrat method (Kershaw, 1973). The qurdrats of $10 \mathrm{~m}$ x $10 \mathrm{~m}$ for trees, $5 \mathrm{~m} \times 5 \mathrm{~m}$ for shrubs and $1 \mathrm{~m} \times 1 \mathrm{~m}$ were laid down for the estimation of quantitative data. For tree, two quadrats were laid at every $100 \mathrm{~m}$ increment of elevation, starting from $1600 \mathrm{~m}$. Individuals of tree species were classified into tree, sapling and seedlings (IFRI, 1994). Altogether 24 quadrats for trees, 48 for shrubs and 96 for herbs were studied. For that two sub quadrats $(5 \mathrm{~m} \times 5 \mathrm{~m})$ were laid down in two corners of the $10 \mathrm{~m} \times 10 \mathrm{~m}$ quadrate for shrub and four sub quadrats $(1 \mathrm{~m} \times 1 \mathrm{~m})$ were laid down in four corners of the $10 \mathrm{~m} \times 10 \mathrm{~m}$ quadrats.

Specimens of all species were collected and the herbarium prepared as used for identification. Some of the plants were identified using standard references (Hara et al. 1978; 1979 and 1982, Stainton, 1988; Shrestha, 1998) and others with the help of specimens deposited at Tribhuvan University Central Herbarium (TUCH) and National Herbarium and Plant Laboratory, Kathmandu (KATH). For nomenclature Press et al. (2000) was followed.

Field data were used to calculate density, frequency, basal area, their relative values and importance value index following Zobel et al. (1987).

\section{Density and relative density}

Density represents the numerical strength of the species in a community.

Density $(\mathrm{p} / \mathrm{ha})=$

$\frac{\text { Total number of individual of a species }}{\text { Total no. of quadrat studied } \times \text { Area of a quadrant }\left(\mathrm{m}^{2}\right)} \times 10,000$

Relative density is a proportion of density of a species with respect to total density of all species.

Relative density $(\%)=$

$\frac{\text { Density of species 'A' }}{\text { Total density of all species }} \times 100$




\section{Frequency and relative frequency}

The frequency and relative frequency was calculated using following formulas.

Frequency $(\%)=$

$\frac{\text { Total no. of plots in which a species 'A' occurred }}{\text { Total no. of plots sampled }} \times 10,000$

Relative frequency $=$

$$
\frac{\text { Frequency of species 'A' }}{\text { Total frequency of all species }} \times 100
$$

\section{Basal area and relative dominance}

It is measured from diameter at breast height (dbh) and its basal area was calculated. It is one of the chief characteristics to determine dominance. So, relative dominance was determined as the relative value of basal area.

$$
\text { Basal Area }=\pi(\mathrm{dbh})^{2} / 4
$$

The relative dominance was calculated as follows: Relative dominance $(\%)=$

$$
\frac{\text { Basal Area of a species }}{\text { Total Basal Area of all species }}
$$

\section{Importance value Index (IVI)}

IVI is the sum of relative density, relative frequency and relative dominance of a species in a community. The IVI value of any species in community ranges between 0-300 and the sum of IVI of all species is 300.

\section{Similarity Index (IS)}

IS was calculated as Sorrenson's index modified by Greig-smith (1964).

$$
\text { IS }=\frac{2 C}{A+B} \times 100
$$

Where, $A=$ Total no. of species in one sample

$\mathrm{B}=$ Total no. of species in another sample

$\mathrm{C}=$ Total no. of common species in both the sample

Table 1: Number of species at different altitude

\begin{tabular}{lccc}
\hline & Site I & Site II & Site III \\
& $(\mathbf{1 6 0 0} \mathbf{- 1 8 0 0 m )}$ & $\mathbf{( 1 9 0 0 \mathbf { m } - 2 3 0 0 m )}$ & $\mathbf{( 2 4 0 0 \mathbf { m } - 2 7 3 2 m )}$ \\
\hline Tree & 22 & 25 & 10 \\
Shrubs & 29 & 37 & 17 \\
Herb (rainy) & 28 & 36 & 27 \\
Herb (dry) & 17 & 26 & 23 \\
\hline
\end{tabular}

Species diversity and index of dominance

Among the several indices, most commonly used two indices are Simpson's index (Simpson, 1949) and Shannon-Wiener's index (Shannon and Weaver, 1949). Simpson's index (C) reflects dominance and Shannon-Wiener index $\left(H^{\prime}\right)$ reflects species diversity. It was calculated as follows:

$$
\begin{gathered}
\mathrm{C}=\sum_{\mathrm{i}=1}^{\mathrm{S}}(\mathrm{Pi})^{2} \\
\mathrm{H}^{\prime}=\underset{\mathrm{i}=1}{\mathrm{~S}}(\mathrm{Pi})^{2}(1 \mathrm{nPi})
\end{gathered}
$$

Where, $\mathrm{C}=$ Simpson's index of dominance

$\mathrm{S}=$ total number of species

$\mathrm{Pi}=$ Proportion of all individuals in the sample that belongs to Species $i$

$H^{\prime}=$ Shannon-Wiener Index

The study area had natural forest which has been protected for more than three decades. Grazing and collection of fallen branches for wood fuel were frequent while felling for timber was not observed. Altogether 147 species (36 trees, 37 shrubs and 74 herbs) belong to 125 genera and 58 families were reported from the study site. Numerically important families were: Asteraceae (16 spp), Rosaceae (9 spp) and Poaceae (8 spp). Nearly half of the species were herbs. The number of herb species was higher in rainy season than in dry season. Site II was rich in number of species for all plant habits. The variation of total species richness along the elevation gradient is shown in the following table.

The highest number of species (109) was found in site II. This may be due to the transition zone of sub-tropical and temperate zone. This site acts as ecozone. But in site III comparatively lower no. of species were reported. This may be due to the mature forest with almost closed canopy and trees were large; so the number of species was low. In case of site I,

\section{Results and discussion}


the lower number of species in comparison with site II may be due to more acidic soil as this is pine dominated forest. The pattern of distribution of plant species was not uniform according to altitude due to variation in micro-climate.

At lower altitude Pinus roxburgbii is dominant among tree species. The major associate tree species are Alnus nepalensis, Schima wallichii, Lyonia ovalifolia etc. Generally pine forest has less number of biodiversity compared to broadleaved but here higher diversity was reported in pine forest rather than broadleaf forest. That may be due to mature forest with almost closed canopy and trees were large; so the tree density was low in the broadleaf forest. Phyllanthus parvifolius is most dominant species among shrub species. Melastoma malabaricum, Berberis aristata, Sarcocca coriaceae, Crotalaria cytisoides, Osyris wightiana, Antidesma acuminatium were associated common species. Eupatorium adenophorum is the most dominant species among herbaceous species.

At middle altitudinal range, Rhododendron abroreum and Quercus lanata were frequently dominant among the tree species and major associated species are Castanopsis tribuloides, Quercus glauca, Symplocus ramosissima, Myrsine capitellata, Gaultheria fragrantisima among shrub and Melastoma malabaricum, Berberis aristata, Sarcocca coriaceae, Crotalaria cytisoides, Osyris wightiana were associated common shrub species and Chlorophytum nepalensis among herbs. Here the number of Castanopsis tribuloides was higher with lower basal area as well as IVI value.

At higher altitude, Quercus semecarpifolia was dominant among tree specie with IVI value 108.37 followed by Rhododendron arboretum (81.07) with Quercus lamellosa, Persea duthiei and Eurya acuminata as major associated species, Daphne bholua among shrub species. The common associated species were Berberis asiatica, Rubus acuminatus, Rubuspaniculatum, Lindera pulcherrima, Indigofera atropurpuria, Arundinaria falcata and Aconitum ferox among herbaceous species, which were ecologically most important species in the study area. The most noteworthy thing was that variation in flower colour of Rhododendron arboreum i.e. deep scarlet at low altitude, but it gradually changed into pinkish white as altitude increased (above $2450 \mathrm{~m}$ ).

\section{Important Value Index (IVI)}

The important value index provides a quantitative basis for the classification of community. The IVI value of any species in community ranges between $0-300$ and the sum of IVI of all species is 300. In site I, the highest IVI (68.19) was recorded for Pinus roxburghii followed by Lyonia ovalifolia (24.41), Alnus nepalensis (21.16). Similarly, the lowest IVI (3.26) was recorded for Eriobotrya elliptica. In site II, the highest IVI (45.71) was recorded for Rhododendron arboreum followed by Quercus lanata (45.43) and Quercus semecarpifolia (37.85). Similarly, the lowest IVI (2.03) was recorded for Theaceae sp. In site III, the highest IVI (108.37) was recorded for Quercus semecarpifolia followed by Rhododendron arboreum (81.07). Similarly, the lowest IVI (5.33) was recorded for Lindera nacusua. It means these species are ecologically important to maintain the existing ecosystem.

\section{Index of Similarity (IS)}

The similarity index value ranged between $18.75 \%$ and $62.82 \%$ for trees, $17.39 \%$ and $45.45 \%$ for shrubs/ saplings, $14.54 \%$ and $37.5 \%$ for herbs/seedlings in rainy season and $10 \%$ and $27.9 \%$ for herbs in dry season. The most frequent and common species have greater role on similarity between two stands (Podani, 1978). So, variation in altitudinal range is the most important factor for determining the IS. It may also be due to the different topography and edaphic factors. Floristic similarity is the response of species to the micro and macro environment (Krebs, 1972). The highest value of IS (62.82) was recorded between site I and site II for tree species and 45.45 for shrub/ sapling between same sites. This may be due to more common tree and shrub species between site I and II. While this value was highest between site I and Site III for both rainy and dry season i.e. 47.6 and 53.06 respectively. For all type of plants the value was lowest between site I and Site III 18.75, 17.39, 14.54 and 10.0 respectively. This may be due to less common species and variation in altitude.

The index of similarity value for tree species was found to be highest $(62.82 \%)$ between site II and I and lowest (18.75) between site I and III. In case of shrub, the highest IS (45.45\%) was found between sites I and II. while lowest (17.39\%) between site II and I. In case of herbs, the highest IS was found between site II and site III in both seasons i.e. rainy $(47.6 \%)$ and dry (53.06\%). Similarly IS was the lowest between site II and I in both seasons. 
Table 2: Index of similarity (\%) of trees, shrub/saplings and herbs/seedlings between different sites

\begin{tabular}{lccc}
\hline \multicolumn{1}{c}{ Habit } & Site I and II & Site II and III & Site I and III \\
\hline Tree & 62.82 & 34.28 & 18.75 \\
Shrub/Sapling & 45.45 & 40.74 & 17.39 \\
Herbs/seedling (rainy) & 37.50 & 47.60 & 14.54 \\
Herbs/seedlings (Dry) & 27.90 & 53.06 & 10.00 \\
\hline
\end{tabular}

\section{Species richness and species diversity}

Species diversity is the combination of species richness and species evenness. Species evenness is the distribution of individuals among the species. The total number of tree species (species richness) was the highest in site II but species diversity (2.64) was higher in site I. Despite of higher species richness in site II, contribution of single dominant species was high in site III had higher Simpson's index (0.1898) because the index was more sensitive to dominant species.

Shrub species richness was higher (37) in site II. Species richness (17) and species diversity were low in site III but index of dominance was high. The evenness was low and dominance concentrated to a single species. For shrubs, the index of dominance ranged from 0.036 to 0.116 and species diversity from 2.45 to 3.39 . For herbs index of dominance was high in site III (0.046) as there were lowest number of species richness with lowest value (0.032) was recorded in site II as there were highest number of species richness in rainy season. It was because, higher the number of individuals, lower their contribution to make dominancy. Reverse type of result was recorded; in case of species diversity i.e. species diversity was directly proportional to total number of species while index of dominance was inversely proportional to species richness. Similar result was recorded for herbs in the dry season.

\section{Conclusion}

Altogether 147 (36 trees, 37 shrubs and 74 herbs) species belonging to 125 genera and 58 families were reported from the study site. Species richness in terms of species number was greatly contributed (about $50 \%$ ) by herbaceous species. The numbers of herbaceous species were higher in the rainy season than in dry season.

Pinus roxburghii was the ecologically most important tree species in lower altitude. At mid elevation Rhododendron arboreum and Quercus lanata were the most frequent and dominant species. At the higher altitude Quercus semecarpifolia was the most dominant species. This result shows the three distinct forest types in the study area. The major associated tree species were Alnus nepalensis, Schima wallichii, Lyonia ovalifolia etc. at lower altitude, Castanopsis tribuloides, Quercus glauca, Symplocus ramosissima, Myrsine capitellata at middle altitude and Quercus lamellosa, Persea duthiei and Eurya acuminata at higher altitude.

Among shrubs and saplings, Phyllanthusparvifolius was the most frequent and dominant species at lower altitude and Melastoma malabaricum, Berberis aristata, Sarcocca coriaceae, Crotalaria cytisoides, Osyris wigbtiana, Antidesma acuminatium etc. were associated common species. In middle range Gaultheria fragrantissima was most frequent and dominant species with association of Phyllanthus parvifolius, Mussaenda frondosa, Hypericum

Table 3 : Species richness (S), Diversity Index (H) and Index of dominance (C) of tree, shrub/sapling and herb/seedling layers in different altitudes

\begin{tabular}{|c|c|c|c|c|}
\hline Altitude (site) & Habit & $\mathbf{S}$ & $\mathrm{C}$ & $\mathbf{H}$ \\
\hline \multirow{4}{*}{$\begin{array}{c}\text { Site I } \\
(1600 \mathrm{~m}-1800 \mathrm{~m})\end{array}$} & Tree & 22 & 0.078 & 2.76 \\
\hline & Shrub/sapling & 29 & 0.093 & 2.80 \\
\hline & Herb/seedling (Rainy) & 28 & 0.042 & 3.08 \\
\hline & Herb/seedling (Dry) & 17 & 0.079 & 2.68 \\
\hline \multirow{4}{*}{$\begin{array}{c}\text { Site II } \\
(1900 \mathrm{~m}-2300 \mathrm{~m})\end{array}$} & Tree & 25 & 0.082 & 2.73 \\
\hline & Shrub/sapling & 37 & 0.367 & 3.39 \\
\hline & Herb/seedling (rainy) & 36 & 0.328 & 3.45 \\
\hline & Herb/seedling (Dry) & 26 & 0.592 & 2.99 \\
\hline \multirow{4}{*}{$\begin{array}{c}\text { Site III } \\
(240 m-2732 m)\end{array}$} & Tree & 10 & 0.189 & 1.91 \\
\hline & Shrub/sapling & 17 & 0.116 & 2.45 \\
\hline & Herb/seedling (Rainy) & 27 & 0.467 & 3.04 \\
\hline & Herb/seedling (Dry & 23 & 0.059 & 2.95 \\
\hline
\end{tabular}


cordifolium, Daphne bholua, Arundinaria falcata. In higher altitude Daphne bholua was most frequent and densely distributed species. The common associated species were Berberis asiatica, Rubus acuminatus, Rubus paniculatum, Lindera pulcherrima, Indigofera atropurpuria, Arundinaria falcata etc.

Regarding herbs and climbers Eupatorium adenophorum and Cymbopogon citratus were most frequent and dominant species at lower altitude in both seasons. In middle altitudinal range Chlorophytum nepalensis makes its dominancy in both seasons. But in higher altitudinal range Aconitum ferox was the most important species during rainy season and Chlorophytum nepalensis during dry season. The other common herbaceous species were Cyperus rotundus, Bidens pilosa, Saccharum spontaneum, Desmodium concinum, Scutelaria discolor, Achyranthus aspera, Potentilla fulgens, Chirita urticifolia, Smilex aspera, S. lanceolata, Cyanodon dactylon, Rubia manjith, Plectertus mollish, Fragaria nubicola, Digitaria ciliaris.

Species richness was highest in the middle range of altitude. Species diversity among tree and shrub species was higher in site I. But for herb species diversity was higher in site II for both seasons. Index of dominance for tree and shrub species was highest in site III but for herbs index of dominance was highest in site I in dry season and in site III for rainy season.

\section{Acknowledgement}

I am highly acknowledged to Professor Dr. H.D. Lekhak and Mr. Bharat Babu Shrestha Central Department of Botany, for their valuable guidance, encouragement, valuable suggestion and critical comment in successful completion of this work. I also thankful to Professor Dr. P.K. Jha, Head of Central Department of Botany for providing necessary laboratory facilities, Professor Dr. K.K. Shrestha and staff of National Herbarium and Plant Laboratories, Godawari for their help in identification of the unknown plant species. DNPWC and SNP are due of thanks for their permission to work in this area. The anonymous reviewer is also thankful for reviewing this paper.

\section{References}

Bajracharya, M.K. 1999. Forest of Nepal In Nature's paradise (eds. T.C. Majpuria), white Lotus Co. Ltd. Bangkok, Thailand pp 112-129.
Bhuju, U. R, Shakya, P. R., Basnet, T. B. and Shrestha, S. 2007. Nepal Biodiversity Resource Book. United Nations Environment Programme (UNEP), Ministry of Environment Science and Technology (MoEST), Government of Nepal.

BPP 1995. Biodiversity profile of the mid hills physiographic zone. GON/Government of the Netherlands.

Chaudhary, R.P. 1998. Biodiversity in Nepal: Status and Conservation. S.Devi, Saharanpur (U.P.), India and Tec. Press Books, Bangkok, Thailand.

Dahlen, J. 1993. Shivapuri Integrated Watershed Management Plan, Nepal, FAO, Rome (Italy). Forestry Dept

DNPWC 2003. Protected Areas of Nepal. DNPWC, Kathmandu, Nepal.

DFRS 1999. Forest Resources of Nepal (1987-1998). FRISP Publication No. 74. Kathmandu, Nepal

Dobremez, J.F. 1980. Carte Ecologie du Nepal Region: Jumal Saipla. Pp 1-5.

DPR (2001). Flowering plants of Nepal (Phanerogams). Ministry of Forest and Soil Conservation, National Herbarium and Plant Laboratories, Godawari Phulchowki Forest) In T.C. Majpuria (ed.) Nepal. Nature's paradise, Lotus studio Bangkok pp. 427.

FAO 1991. Project Document-Shivapuri Integrated Watershed Development Project Phase II. GCP/ NEP/ 048/NOR.

Greig Smith, P. 1964. Quantitative plant Ecology III ${ }^{\mathrm{rd}}$ Edition, Butterworths, London.

Greig Smith, P. 1964. Quantitative plant Ecology II ${ }^{\text {nd }}$ Edition, Butterworths, London.

Hara, H. and L.H.J. Willams (eds.) 1979. An Enumeration of the Flowering Plants of Nepal. Volume II. Brit. Mus. (Nat. Hist.) London.

Hara, H., A.O. Chater and L.H.J. Willams (eds.) 1982. An Enumeration of the Flowering Plants of Nepal. Volume III. Brit. Mus. (Nat. Hist.) London.

Hara, H., W.T. Steran and L.H.J. Williams (eds.) 1978. An Enumeration of the Flowering Plants of Nepal. Volume I. Brit. Mus. (Nat. Hist.) London. 
IFRI 1994. IFRI Data collection Instruction Manual, May 1994, version 7. International Forestry resources and Instruction (IFRI), Research Programme. Workshop in Political Theory and Policy Analysis Indiana University, Bloomington, Indiana, USA.

Jackson, J.K. 1994. Manual of Afforestation in Nepal. Forest Research and Survey Center, Ministry of Forest and Soil Conservation, Kathmandu, Nepal.

Kershaw, K.R. 1973. Quantitative and Dyanamic plant Ecology. Edward Arnold Limited London.

Krebs, C.J. 1972. Ecology. The Experimental Analysis of Distribution and Abundance. Harper International Edition.

LRMP 1984. Land Utilization Map. Topographical Survey Branch, Survey Department, HMG/ Kenting Earth Sciences Ltd. Canada.

MOPE 2003. State of the Environment in Nepal. Ministry of Population and Environment, Kathmandu.

Numata, M. 1983. Ecological Studies in the Nepal Himalayas. In M. Numata (ed.) Ecology and conservation, the selected paper of Makotot Numata: 247-259. The Himalayan Committee of Chiba University, Japan.

Podani, J. 1978. A method for clustering of binary (Floristical) data in Vegetation research. Acta Bot. Acad, Sci. Hung, 24: 121-137.
Press, J.R., K.K. Shrestha and D.A. Sutton 2000. Annotated Checklist of the Flowering Plants of Nepal. Natural History Museum, London.

Shrestha, K. 1998. Dictionary of Nepalese Plant Names. Natural History Museum, Mandala Book Point Kathmandu.

Sigdel S. R. 2004. Vegetation and Soil Analysis in Southern Aspect of Shivapuri National Park, Nepal, M.Sc. Thesis submitted to Central Department of Botany, T.U., Kathmandu, Nepal.

Simpson, E.H. 1949. Measurement of diversity. Nature 163: 688.

Stainton, J. D.A. 1972. Forest of Nepal, John Murray Publisers, Ltd.

Stainton, J.D.A. 1988. Flowers of the Himalaya. Oxford Press, New Delhi, India.

Tamot (Shrestha), B., G.P.S. Ghimire and S.B. Karmacharya 2000. Vegetation distribution in relation to soil surface characteristic in Shivapuri watershed Area, Nepal. Eco-print 7(1): 43-47.

TISC 2002. Forest and Vegetation type of Nepal. Tree Improvement and Silviculture Component (TISC), Department of forest, Kathmandu. Document series No. 105. 180 p.

Zobel, D.D., P.K. Jha, J.M. Behan and Yadav, U.K.R. 1987. A Practical Manual for Ecology. Ratna Book Distributor, Kathmandu, Nepal. 